\title{
Etymology and Ideology: Substratum Heritage and the Slavic Influence on Romanian
}

Sorin Paliga

(Bucharest, Romania)

\section{Abstract:}

The paper focusses on the influence of ideological (political) issues on linguistic studies, specifically on the long debated issue of substratum heritage of Romanian. Though often downplayed, the ideological (in most cases political) dimension of humanistic studies is obvious, and it explains some of the approaches to history and, in our case, to historical linguistics that one observes. The general situation is described through some case studies. In the second half of the 19th century, the field was dominated by the outstanding personality of Bogdan Petriceicu Hasdeu. After his death, there was no significant approach to the complex and difficult problems related to the substratum of Romanian, or to other problems in comparative analyses. No consistent and coherent approach to these issues emerged until the late 1960's, i.e. almost a century later! Between 1969, when the first relevant analysis was published, and the 1980's, when most such studies were published, little of value appeared, despite the volume of material published. Their results were more amateurish than reliable. Though the study of the substratum heritage it is often associated with extreme nationalism or other forms of political extremism ('extreme right' or 'extreme left' or whatever), including those recent variants labelled 'thracomania' or 'dacomania' and other amateurish approaches to the topic, the problem of Romanian's substratum heritage is nonetheless a complex, difficult and fascinating one. It will continue to present a challenge as long as there is no consensus among linguists. Substratum influence has more often been underestimated than exaggerated; the number of substratum elements seems to be considerably higher than the currently accepted 200 hundred words, a total that 
seems to have been uncritically copy-pasted from one author to another. This paper tries to give a new impetus to research in the field. The author has discussed other aspects of the field elsewhere.

\section{Key words:}

ideology; politics; substratum; Indo-European; Romanian; Albanian; Slavic

\section{Premises}

Historical linguistics, just like history in general, has always been 'imbued' with various ideological approaches to the analysis proper. Even if this is obvious, or even because it is too obvious, the ideological aspects of scientific research have often been neglected. Ideology is related to politics and the political, to the social and socio-psychological concepts dominating the period in which the scientific investigations in question were undertaken. I will conventionally use terms like ideology and ideological to refer to such aspects, i.e. to cover a large range of conceptions closely or remotely related to politics, mindset and social context.

One's ideology is a complex phenomenon in itself, involving various social and cultural components accumulated over time. Some reflect the social ideology accumulated at home, others reflect information accumulated during the school years. This is why education has had a crucial role in all aggressive political systems like communism or Nazism: children must obey certain rules, as they are called upon to become the future builders of 'new societies'. For some, such 'ideological constructs' have little influence; for others they have a tremendous influence in constructing a certain, specific approach to history and to the interpretation of all accompanying historical events. Ultimately, ethnicity-with its complex historical consequences-has always been connected to politics and to ideology. History is, above all, the history of political events. To a less extent, though not in all cases, it is a history of social and psychological events.

I recently tried to show how ideology and political bias have deeply influenced the long debated issue of Albanian ethnogenesis, and how ideology has become a component of the debate. ${ }^{1}$ This is, I think, a typical example of how ideology has deeply influenced academic analysis. It is a debate that has developed over a long period, from the second half of the 19th century to our own time, and has thus involved

1 PALIGA, S.: The Albanian Ethnogenesis, an 'Enigma'? A brief answer to Genc Lafe. In honorem Dagmar Maria Anoca. Ed. by Antoaneta Olteanu. București: Editura Universității București, 2016, pp. 303-316. 
several political contexts and, therefore, ideologies. It is not, of course, the only case, and this paper tries to suggest another case of ideologic intrusion into the scientific research. I shall try to sketch the main ideological constructs which have had a certain, sometimes essential, influence in Modern Romania from the second part of the 19th century until now. Of course, some or most of the relevant factors are shared with other cultural areas too, mainly with the neighbouring Slavic area, even if the local developments may be specific. The modern, scientific approach to the history of southeast European languages and of their speakers as ethnic groups may be dated in the second half of the 19th century, though there were attempts in earlier periods, of which Dimitrie Cantemir's Descriptio Moldaviae is an outstanding example.

The end of the 18th century and beginning of the 19th century are recognized as landmark periods in modern science, both technical and humanistic. In Central and Southeast Europe, these developments spread later, mainly after 1848, the year of the European social and political revolutions. This corresponds to the Romantic and Post-Romantic period, with the gradual construction of national identities ('ethnicization') in the area and, consequently, with the gradual decay of the Ottoman Empire. On a larger European scale, which cannot be expounded upon in this brief study, there was an enthusiastic approach to science, to the recently discovered hypothesis of the Indo-European origin of most languages spoken in Europe and a large part of Asia.

In the 2nd half of the 19th century there was a general acceptance of these new theories, which was amplified by a fervent approach to history and to new political concepts like independence, national revival etc. On the other hand, the sometimes narrow approach to history and to national mentalities also imply xenophobia, intolerance, ignorance, biased analyses, superficiality. These are not exactly specific to this period of European history, but they should be included in the analysis as a relevant part of the story.

Historical and comparative linguistics has been chosen as a relevant field because, just like history, it is equally sensitive to ideological (read: political) influence. It is inevitably linked to history proper which, in turn, is largely the political history of mankind. This is why 'sensitive topics' like the origin of the Albanians, Romanians, the migration and post-migration period of the Early Middle Ages, the 'making' of the Slavs (I use here Florin Curta's phrasing), the Mid-Middle Ages etc. have often remained the subjects of contentious political debates rather than 'objective' discussions. The following pages will offer just a sketch of a complex problem. The focus is on the specific case of Romanian, Romanian-Slavic and Romanian-Albanian relations, but similar and/or related discussions may refer to other cultural and/or linguistic areas too, e.g. Albanian, Bulgarian-or Slavic, in general -, Hungarian as relevant examples more or less connected to the facts described below. There are similarities and differences in 
these cultural and linguistic areas. The purpose of this paper is to sketch and/or note some observations rather than solve them or suggest solutions to solve them.

\section{Central and Southeast European Revival}

If we limit our analysis to Central, East and Southeast Europe, i.e. to the Slavic area and adjacent parts of Europe, including what is now Romania, which at the time were the united principalities of Wallachia and Moldavia (unified in 1859), several features of that age should be pointed out. Two are essential for understanding the making of history in those days, including cultural history.

First of all, there was a period of 'national enthusiasm' in the wake of this unification, accompanied by a series of major achievements in the financial and social field.

Secondly, there was a remarkable development of culture, unparalleled up to that time.

The dominant ideology of the and half of the 19th century is national, not without occasional traces of nationalism. It gradually developed into the aggressive ideology of the extreme right wing ideology that later characterised the interwar period in many European countries. Nationalism was considered normal and was a direct consequence of the political changes. The Latin origin of Romanian was widely celebrated, with the implicit consequence that any (Thracian) substratum, Slavic or Hungarian influence had to be deprecated or entirely ignored. From the perspective of Romanian nationalism, only the Latin origin of the language was relevant, the rest was Barbaricum, therefore irrelevant to the national history.

In the Czech and Slovak area, two personalities should be mentioned: Pavol Jozef Šafárik and Ján Kollár, two Slovaks with Czech education, as was usual in those times. They built a specific ideology of Slavism which affected all the subsequent development in this field. The ample and complex activity of Šafárik has been recently reviewed from the perspective of the Romanian-Slavic relations, with the argument that he was in fact the first to systematically analyze these relations, and not Miklosich as currently accepted. ${ }^{2}$

In Hungary, the historian Pál Hunfalvy should be mentioned.

In the south Slavic world, the Serbs and the Croats aimed at a common literary language, therefore the tendency was towards cultural synthesis, not towards a split. As a consequence, the concept of the Serbo-Croatian language was born. Now, in some linguistic papers, usually published outside Serbia or Croatia, the term occasionally

2 IONESCU, A. I.: Pavel fosef Šafař́k și slavistica românească. București: Oscar Print, 2017, pp. 20, 23. This seems to be the most recent and consistent analysis of Šafárik's contribution to the Romanian-Slavic relations. The study is followed by an ample abstract in English, and a fragment referring to these relations. 
used is Serbian-Croatian which seems to have replaced Serbo-Crotian. At official level, one has to deal with four literary and cultural traditions, in alphabetical order Bosnian, Croatian, Montenegrin (Crnogorski) and Serbian, or BCMS area.

An important expression of Romanticism and, in our case, Post-Romanticism is the cult of history, of heroes, of the past in general. This attitude directly affected how historians and linguists analyzed history and, implicitly or explicitly, historical linguistics and historical studies in general. Note that comparative Indo-European studies were already well established by the mid 19th century, and Finno-Ugric studies followed soon after. Almost all the salient details of Indo-European phonetic evolution were well established. Hittite was added in the zoth century (precisely in August 1915 when Bedřich Hrozný published his first paper on the decipherment of Hittite), and with it the issue of the so-called laryngeals, already anticipated by Saussure in 1878 .

Finally one must note Illyrism, which had a remarkable turn in the and half of the 19th century: until then, 'Illyrian' had been the name for the Croatian language. When the Croats developed their distinct ethnic identity, an instance of the remarkable process of the gradual ethnicization of the European groups, and the concept of a Serbo-Croatian language was created, Illyrism lost its original meaning and began to be applied to the Albanian language, and has remained associated with that language until now. ${ }^{3}$ Needless to say, neither the Croats nor the Albanians are direct descendants of the ancient Illyrians, but this has no relevance, in fact, when ideology (read: politics) is considered more important than science itself. Unfortunately this has been the reality of the last century in southeast Europe, with ups and downs, and with many tragic developments after 1991 in former Yugoslavia.

This is, briefly sketched, the ideological and political tableau of the 2nd half of the 19th century in Europe, and with its implications, some of them surviving until now. Let us now concentrate on the Romanian language and main structure from the perspective of a Romance language but with a relevant substratum heritage and later with important Slavic, to a less extent Hungarian, influences. The Romanian-Slavic relations have remained a much debated topic in the history of the Romanian language, perhaps the most persistent. Until reliable statistical data are available, I would say that the Romanian-Slavic relations represent a more important reference point in the history of the Romanian language than the Latin heritage itself. They are, by far, more insistent and more intense than the debates on the substratum heritage. But, as already revealed, the problem of the substratum influence intermingles with the 'Slavic issue' and, sometimes, with the 'Hungarian issue' in the studies dedicated to the history of the Romanian language. Almost always, explicitly or implicitly, the

3 On Illyrism see recently BLAŽEVIĆ, Z.: SRPSKI ilirizam prije ILIRIZMA: NACIONALNO-IDENTIFIKACIFSKI modeli u historiografskim djelima grofa ĐORĐA BRANKOVIĆA (1645-1711). Književna istorija 44, 146, 2012, pp. 23-39. 
ideological background has always been inevitable, often persistent and, not rarely, with violently polemical attitudes.

Bogdan Petriceicu Hasdeu is by far the most prominent figure of the and half of the 19th century in Romania if we refer to humanistic studies in general: editor of Old Church Slavonic texts and the first Slavist in Romania, author of the first comparative grammar of the Indo-European languages to be published in Romania; the first to analyze and define the influence of the substratum; the first to offer brilliant etymological explanations, e.g. Rom. doină, dial. daină related to Lithuanian dainà, Latvian dainga. All these forms refer to local, specific folk songs in Romanian, Lithuanian and Latvian, respectively. Note that the regional typology of Romanian doina was later used by Béla Bartók to classify the Romanian folk melodies. Hasdeu was the first to show the north Danubian (Dacian) origin of the Albanians. His theory was later adopted and developed by Giuliano Bonfante ${ }^{4}$ and I. I. Russu ${ }^{5}$. A variant of this theory was developed after WWII by the so-called Bulgarian school of Thracology, differing only in that the latter have been developing the hypothesis of the 'Balkanic' origin of the Albanians, i.e. a migration of the Thracian groups located in the Stara Planiná under pressure from Slavic groups. It may ultimately prove to be the case that the Neo-Thracian character of Albanian will be explained by both north and south Danubian developments. In the approach I have in mind, both north Danubian, presumably Carpian, and south Danubian, 'Balkanic' groups, moved southwards under pressure from the Slavs moving both north-to-south and east-to-west, as was the case for most migrations in those times, in fact. The role of the Carpians in antiquity, including after the Roman conquest of Dacia, has been much analyzed, e.g. the classical books of Gheorghe Bichir ${ }^{6}$ and the scientific journal Carpica ${ }^{7}$. These analyses, some of them important and reliable, are generally unknown to the general, non-specialized readers as they require references to archaeological and comparative historical research, which is not an easy task, for sure.

4 BONFANTE, G.: Studii române. București: Saeculum I. O., 2001; translated after BONFANTE, G.: Studii romeni, Società Accademica Romena, Collana di studii e saggi, VI, Roma, 1973).

5 RUSSU, I. I.: Obîrșia tracică a românilor și albanezilor. (Clarificări comparativ-istorice și etnologice). Der thrakische Ursprung der Rumänen und Albanesen. (Komparativ-historische und ethnologische Klärungen). Romanian-German bilingual edition, translated by Konrad Gündisch. Cluj-Napoca: Dacia, 1995 (posthumous). The authors resumes and enhances the old hypothesis of Hasdeu regarding the North Thracian (specifically Carpian) origin of the Albanians.

6 His works remain fundamenal and seemingly unsurpassed as synthetic approaches to the problem of the so-called 'Free Dacians'. BICHIR, G.: Cultura carpică. Bucureşti: Editura Academiei, 1973; BICHIR, G.: Dacii liberi din Muntenia şi relaţiile lor cu romanii. Thraco-dacica 2, 1981, pp. 73-92; BICHIR, G.: Ramura nordică a dacilor-costobocii. Thraco-dacica 4, 1-2, 1983, pp. 59-68; BICHIR, G.: Geto-dacii din Muntenia în epoca romană. Bucureşti: Editura Academiei, 1984.

7 It is partially available online as PDF format: Enda - Carpica. <http://www.enciclopedia-dacica.ro/? operatie $=$ subiect $\&$ locatie $=$ periodice $\&$ fisier $=$ carpica $>$. [online]. [cit. 10-28-2020]. 
Hasdeu was also responsible for many exceptional explanations, e.g. that the origin of Rom. zglobiu 'frolic child' is Slavic zlobivz 'somebody who gets angry or furious' < zlo 'bad, wicked', cf. Czech zlobivé ditě, with the same meaning as in Romanian: 'frolic child'. He thus explained the emergence of an epenthetic, non-etymological $/ \mathrm{g} /$ in the sequence /zl-/, parallel to the non-etymological /k/ in Sclaveni, Sclavini, a development from the original form Slověninz, pl. Slověne. The preservation of this ethnonym in the case of the Slovenes (Slovenec, pl. Slovenci) and the Slovaks (Slovák, Slováci) is the best evidence that this ethnonym was indeed used by some Slavic groups when they reached the Romanized areas, including the Balkans several years later.

Hasdeu's scientific career came to an abrupt end in 1888 by the premature death of his daughter Iulia at the age of 19. From that moment on, he dedicated the rest of his life-he died in 1907, at the age of 69-to spiritualist activity in the desperate attempt to communicate with his daughter. He is also the author of the first manual of spiritism published in Romania. ${ }^{8}$ Hasdeu's essential works in the field of philology, history and linguistics are readily available in several editions. ${ }^{9}$

There were no immediate successors to the extraordinary pioneering activity of Hasdeu, since no school of followers had developed around him to continue his activity in the field of comparative linguistics, the analysis of the substratum influence on Romanian and the Romanian-Slavic relations understood in their complexity, not as simplistic list of words. His historical and linguistic writings remained partially without direct followers, mainly those referring to the survival of some north Thracian

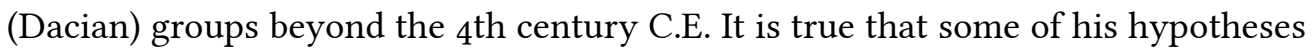
would not be accepted now, but this has little effect on how his outstanding activity is still received. After the death of Hasdeu (in fact, after his 'scientific death' in 1888), Romanian linguistics in general, and Romanian historical and comparative linguistics in particular, abruptly fell to a level from which it only began to recover almost a century later, beginning in the 1960's.

8 All these details may be visited in situ in the Hasdeu museum in Câmpina, some $110 \mathrm{kms}$ north of Bucharest: Muzeul Hasdeu. <http://www.muzeulhasdeu.ro>. [online]. [cit. 28-10-2020].

9 For example, HASDEU, B. P.: Scrieri istorice, I-II. Bucureşti: Albatros, 1973; HASDEU, B. P.: Studii de lingvistică şi filologie. Ed. by Gr. Brâncuş, 2 vols. Bucureşti: Minerva, 1988. For a brief presentation in Czech of Hasdeu's activity, mainly as a Slavist, see: PALIGA, S.: Bogdan Petriceicu Hasdeu: první lingvista a slavista $v$ Rumunsku (Bogdan Petriceicu Hasdeu: the first linguist and slavist in Romania). Literature and Social Change: a Voyage Through the History of Slavic Studies. Proceedings of the International Symposium Literature and Slavic Studies held by the Commission for the History of Slavic Studies at Comenius University in Bratislava on the 12th and 13th of April 2016. Edited by Lubor Matejko. Bratislava: Univerzita Komenského, 2017, pp. 131-140. The most extensive study on Hasdeu from the perspective of his linguistic, historical and philological studies still remains POGHIRC, C.: B. P. Hasdeu, lingvist şi filolog. Bucureşti: Ed. Științifică, 1968. 
Despite the fact that he was conversant with all the Slavic languages-he labelled them 'Slavic dialects'-and with many languages then regularly or rarely in use in scientific work-he spoke Russian, Polish and Lithuanian too-Hasdeu wrote his scientific works in Romanian only. Therefore, his hypotheses were known to very few foreign linguists and historians, so were not widely disseminated.

Hasdeu reflected the spirit of the age as applied to the Romanian context: the analysis of its Latin origins, the influence of the substratum, the relations between Romanian, on the one hand, and the Slavic languages, on the other. These have remained the main topics of debate ever since. It is difficult to place Hasdeu in a strict ideological frame: he rejected the Latinist movement that aimed at exaggerating the Latin origin of Romanian, and he also rejected narrow nationalism. He had frequent polemical exchanges with Šafárik for example, whom he considered a bad linguist, who did not know the elementary principles of comparative Indo-European linguistics. From the perspective of our times, his critical view of Šafárik's linguistic ability seems exaggerated, mainly if one considers Šafárik's pioneering activity in the field of Romanian-Slavic relations, to be later developed by many others linguists and philologists.

He also criticized the Hungarian historian Pál Hunfalvy and his hypothesis regarding the south Danubian (Balkanic) origin of the Romanians. This has remained a topic of contentious debate, periodically revived when the political context 'required' it.

Even if Hasdeu had no immediate followers, one should note some other relevant personalities of those times. One is, without doubt, Heimann Hariton Tiktin, a Jew of Silesian origin who wrote the first comprehensive Romanian-German dictionary with etymological explanations for almost every word. This was and still is very rare in the case of bilingual dictionaries. Tiktin married a Romanian woman, and in 1903 converted to the Christian faith. He was also the first to introduce a program in Romanian at a foreign university.

Some other relevant personalities may be mentioned in this context, but this would require a more extensive treatment than is possible in this brief survey.

From Hasdeu to the 1960's. There was no significant Romanian linguist in the field of comparative and historical Indo-European studies in the interval between the death of Hasdeu (in fact, between his 'scientific death', in 1888) and 1967-1968! There has been no significant and comprehensive study or book dedicated to this topic. It seems that the problem was in the ideologies underlying the study of the subject rather than the subject matter itself, or perhaps a combination of both. This is a remarkable situation, given the fact that after WWI a series of relevant studies were published in many countries, mainly in Western Europe. One notes the appearance of studies of Europe's Pre-Indo-European heritage mainly in Italy, but also in France and the former Yugoslavia (some time later, after WWII). Petar Skok and his study 
dedicated to the place-names of the Adriatic Coast remains unsurpassed so far. ${ }^{10}$ The principles of analysis established by Skok remain valid for any similar attempt, mainly referring to southeast Europe.

It seems that, in general, the inter-war period was marked by two personalities in Romania: Al. Philippide, the author of Originea românilor 'Origins of the Romanians', which is a philological history of the Romanian language rather than a history proper ${ }^{11}$; and Sextil Pușcariu, the author of a monograph on the Romanian language. ${ }^{12}$ The standard of their work, and that of others, was much below the level of Hasdeu, in both the depth and scope of their analyses. There was an explosion in arts and culture in Romania after WWI, but only limited activity in the field of linguistics, mainly in the field of historical and comparative linguistics, at least if compared to the outstanding developments in Western Europe or in Czechoslovakia, mainly around the Prague Linguistic Circle.

The contempt with which most Romanian linguists held substratum studies is obvious and indeed relevant to any attempt to explain this peculiar situation, without parallel elsewhere, it seems. Note that Thracology has become a research subject in Bulgaria, including in interdisciplinary research.

It is a matter of mere speculation, misinterpretation and ignorance that substratum studies were compromised by the extreme right in the 1930's. In fact, neither before nor after this historical period was the substratum the focus of much investigation. The 1930s witnessed the first works by two important Romanian personalities: Mircea Eliade, later known mostly for his analyses in the field of the history of religions; and Emil Cioran. Both began their cultural activity in adherence to the ideology of the extreme right, and both later became known as significant figures in the Romanian anti-communist emigration. But they have no relevance to the study of the substratum heritage of Romanian. This period was indeed characterized by a diverse and rather incoherent mixture of Orthodoxy, xenophobia and nationalism, and was without major lasting reflexes in culture.

After WWII, two very influential linguists should be noted: Iorgu Iordan and Al. Rosetti. Neither were engaged with the substratum problem, and both in different ways seemed reluctant to approach it. Both were also strongly supported by the communist régime, and may be considered typical representatives of that new political context in the field of linguistics. Neither made any relevant contribution to the analysis of the substratum influence; on the contrary: Iordan simply ignored it entirely, while Rosetti

10 SKOK, P.: Slavenstvo i romanstvo na jadranskim otocima. Toponomastička ispitivanja. Zagreb: Jugoslavenska akademija znanosti i umjetnosti, 1950.

11 PHILIPPIDE, A.: Originea românilor (the origin of the Romanians), vols. I-II. Iaşi, 1923-1928.

12 PUŞCARIU, S.: Limba română. Bucureşti: Minerva, 1976. 1st ed.: Bucureşti 1940. 
circulated either banalities or wrong directions e.g. 'Albanian influence on Romanian', which has remained (be it isolated) a cliché adopted in some leftist, Neo-Marxist circles up to the present ${ }^{13}$.

Romanian substratum studies were abruptly reinvigorated by Cicerone Poghirc's chapter in the and volume of the History of the Romanian Language. ${ }^{14}$ Note that this is THE FIRST such attempt since Hasdeu's time, 80 years later to be more specific (if we consider the year 1888 as the reference point in Hasdeu's activity). It is not perhaps mere chance that this period, i.e. the second half of the 1960s, reflects the years anticipating the Prague Spring in 1968, a period of relative freedom and relative prosperity so abruptly interrupted in August 1968.

This renewal of interest for this particularly significant field of research was enhanced in 1972 when the Institute of Thracology was created in another political context in Bulgaria, and immediately in Romania. It is not clear whether this had a direct or indirect connection with the general political context in Eastern Europe. For many years, this newly created institute served as a place of interdisciplinary research. It virtually disappeared in 2004, when it was formally unified with the Institute of Archaeology, though it appears to have been revived recently, after the International Congress of Thracology in Kazanlăk, Bulgaria (August-September 2017). After Poghirc's attempt to update Romanian etymology-he also authored a book about Hasdeu (see footnote 9, above)-with similar efforts in other countries, there were a series of other analyses amongst which one might note the works of I. I. Russu' ${ }^{15}$, Mircea Mihai Rădulescu (a noteworthy analyst of the substratum in Romanian, unfortunately almost entirely ignored, and now almost entirely forgotten) ${ }^{16}$; Grigore Brâncuș, a good Albanologist, and familiar with the relationship between Albanian and Romanian ${ }^{17}$; and Ariton Vraciu ${ }^{18}$. A recent attempt belongs to Pârvu

13 ROSETTI, A.: Istoria limbii române, fully revised, final edition. Bucureşti: Editura Ştiințifică şi Enciclopedică, 1986 (with several previous editions).

14 POGHIRC, C.: Influenţa autohtonă, in Rosetti et alii (ed.), Istoria limbii române, 2 vols., 1965-1969, vol. 2, pp. 313-364.

15 RUSSU, I. I.: Etnogeneza românilor. Bucureşti: Editura Științifică și Enciclopedică, 1981; see also footnote 5 , above.

16 RĂDULESCU, M. M.: Daco-Romanian-Baltic Common Lexical Elements. Ponto-Baltica 1 (Editrice Nagard), 1981, pp. 15-113; RĂDULESCU, M. M.: Illyrian, Thracian, Daco-Mysian, the substratum of Romanian. The Journal of Indo-European Studies 12, 1-2, 1984, pp. 77-131; RĂDULESCU, M. M.: The Indo-European Position of Illyrian, Daco-Mysian and Thracian. The Journal of Indo-European Studies 15, 1987, pp. 239-271.

17 BRÂNCUŞ, G.: Vocabularul autohton al limbii române. Bucureşti: Editura Știinţifică şi Enciclopedică, 1983; BRÂNCUŞ, G.: Cercetări asupra fondului traco-dac al limbii române. București: Institutul Român de Tracologie, Bibliotheca Thracologica VIII, 1995; BRÂNCUŞ, G.: Concordanțe lingvistice româno-albaneze. București: Institutul Român de Tracologie, Bibliotheca Thracologica XXX, 1999.

18 VRACIU, A.: Limba daco-geților. Timişoara: Facla, 1980. 
Boerescu, who unfortunately does not provide a coherent list of the criteria he uses for identifying substratal items ${ }^{19}$. He seems to assume that any word whose origin he cannot identify is from the substratum, which may be an acceptable starting point as long as it is accompanied by other arguments.

At this point I should cite another relevant approach to the problem of substratum inheritance: Gheorghe Ivănescu's A history of the Romanian language ${ }^{20}$, perhaps the best of its kind. According to available information, the published version reflects approximately $1 / 3$ of the complete manuscript ${ }^{21}$. Gh. Ivănescu is also co-author of a newer introduction to the study of the Indo-European languages, in which he updated and augmented the lectures of Theophyl Simenschy, both professors at the University of Iași ${ }^{22}$. This is, I think, the only significant example of a general history of Romanian where the substratum influence has an important role.

One might also note the present author, who published a first attempt at an etymological dictionary of the substratum elements of Romanian in 2006. There are some errors in it, but most of the material is, I think, valid and reliable. The addenda to that work, which include some relevant examples of place-names, not only in Romania, but also in neighbouring areas.

An interim conclusion may be that the substratum influence on Romanian has been achieved by linguists who were also Slavists, beginning with Hasdeu in the second half of the 19th c. and later. Vraciu and Ivănescu quoted above were also Slavists. And, last but not least, it is not mere chance that the most constant and coherent analysis of the Thracian (substratum) influence in southeast Europe is due to our Bulgarian colleagues as they inevitably are good Slavists as well and also prepared to better analyze the Thracian heritage of southeast Europe as compared to the Greek and Latin heritage, on the one hand, and the Slavic influence after the 6th c., on the other.

\section{So, why so many problems with the substratum of Romanian in relation with the Slavic influence?}

Romanian began to be recognized as an important language in the field of historical and comparative linguistics beginning in the 2 nd half of the 19th century. At that time, the main focus of Romanian studies was to demonstrate Romanian's Latin origin

19 BOERESCU, P.: Elementele de substrat (autohtone) ale limbii române. Compendiu. București: Editura Academiei Române, 2018.

20 IVĂNESCU, G.: Istoria limbii române. Iaşi: Junimea, 1980.

21 Cezar Ivănescu's personal information, approx. 1985-1986. Cezar Ivănescu, poet and singer, was the nephew of Gheorghe Ivănescu.

22 SIMENSCHY, T., IVĂNESCU, G.: Gramatica comparată a limbilor indo-europene. Bucureşti: Editura Didactică şi Pedagogică, 1981. This continues to be the best and most complete introduction to the historical and comparative analysis of the Indo-European languages ever published in Romania. 
(which is obvious), and to identify the non-Romance influences. Slavic influence was next in focus. Substratum (i.e. Thracian) influence has received far less attention, at least if we look at subsequent research. The study of the substratum has remained peripheral in efforts to clarify the historical development of Romanian. The influence of the substratum is not specific to Romanian, as substrata played an important role in the evolution of all the Romance and non-Romance languages, and explains many of the subsequent developments from colloquial Latin to the Romance languages. What is, therefore, so peculiar in the case of Romanian? It is the fact that Romanian's Indo-European substratum, in contrast to that of other Romance languages, was a Thracian (that is, a satem) substratum, in contrast to the s mainly centum substratum of Western Romance languages. (Note that the word substratum has a specific connotation when used with reference to Italian, where it refers to the substratum of Latin.) It should be also mentioned the great Pre-Indo-European civilisations of southeast Europe, which must have left important traces in place names and vocabulary. Greek offers good examples for such old forms preserved from the Pre-Hellenic substratum, but southeast Europe in general offers such examples.

One tangible reason for the lack of attention to the substratum seems to have been ideological: the Latin structure of Romanian was stressed because it was considered 'noble', in comparison to the more unclear, confused, and fragmentary influence of languages assigned to Barbaricum as the Thracian substratum or the Slavic role in contouring the features of Romanian. It was (and remains) easier to deal with Slavic influence the study of which does not require complex analyses of languages spoken in Antiquity, most of them without written sources. In practical terms: it is easier to analyze the common elements of Romanian, on the one hand, and those of the neighbouring Slavic languages. The complex analyses, as in Skok (see above, footnote 10), are not so easy to achieve just like the complex analyses of Hasdeu in the 19th c.

Despite the influence of the Latinophile movement and the frequent tendency to overstate Latin influence during Hasdeu's era, Slavic influence was also exaggerated: any similarity between a Romanian and a Slavic element was sufficient to consider it a 'Slavic element in Romanian'. Representative cases include that of the numeral sută (Romanian) v. Slavic szto 'one hundred'23 or the relation between Rom. boier and some forms found in neighbouring languages, including the Latinised form boieronatus, the social category of boier $^{24}$. Despite the evidence that these are not Slavic elements in Romanian, they continue to be cited as such in most works. Rom. boier reflects, in fact, the evolution of the meaning 'owner of cattle' to 'rich man' and is etymologically

23 PALIGA, S.: Slovansko * szto - izzivalen problem? (in Slovene with an English abstract: Slavic *szto-a challenging problem?). Slavistična Revija (Ljubljana) 36, 4, 1988, pp. 349-358.

24 PALIGA, S.: Este boieria o instituţie împrumutată? Revista Arhivelor 67, vol. 52, 3, 1990, pp. 250-260. 
related to French family name Boyer, of the same origin: Lat. bos, bovis $>$ Rom. bou, pl. boi, hence boier; just like Lat. Ovis > Rom. oaie > oier 'shepherd'. In any classical society, the owners of cattle and sheep had a higher social rank, as reflected in the Latin forms pecu(s) pecuniosus 'herd, flock' 'rich'. It is regrettable that the etymon of this important social (and political) term has been erroneously assigned to would-be Turkic influence prior to the Ottoman influence. Such a hypothesis has in fact no solid support in any historical or linguistic analysis.

The literary approach to the substratum influence was seemingly easier; for example, in Mihai Eminescu's Rugăciunea unui dac (the prayer of a Dacian, 2nd part of the 19th c.) or Nichita Stănescu's Elegia II. Getica, written in the 1960's. There are well known, valuable and non-controversial literary works.

In recent decades, the issue of substratum influence has been complicated by the rather confusing terminology used in the influential reference work Dicționarul explicativ al limbii române 'Explanatory Dictionary of the Romanian Language', usually known as DEX, that has appeared in several editions beginning in $1975^{25}$. In DEX the ascription 'et. nec.' (etimologie necunoscută 'unknown etymon') is used in an unclear fashion for a range of different cases: substratum elements, words for which several explanations have been offered, words with a quite obvious etymology, but regarding which the authors are apparently wary of making a definitive claim. Note also that DEX never uses the label 'substratum element' except to refer to elements shared with Albanian, which are marked 'cf. Alb.... In fact, the common Albanian-Romanian heritage has greater significance than DEX mentions, and involved both Latin and substratum elements). DEX also mixes up the notion of 'Slavic influence' by invoking unclear, often mis-spelled Slavic forms in order to justify the reference to a given Slavic etymon. As a mere example, DEX fails to note the etymological relationship between Rom. cireadă 'a herd' (used for cattle) which obviously reflects Bg. ̌rr and/or S.-Cr. čreda, OCS črěda, on the one hand, and Rom. cârd 'a large group of animals or birds gathered together, a flock'. This latter form has an obvious centum phonetical structure as compared to cireadă. DEX 'simplifies' the discussion by invoking S.-Cr. $k r d$, which seems an invented form (anyway absent in Skok's etymological dictionary and seemingly absent at dialectal level, e.g. in the Serbian dialects spoken in Romania).

If my analysis is correct, one may assume that the superficial and confusing approach to Romanian etymology in DEX, with regard to the substratum and to other matters, has had a detrimental effect on the etymological analysis. This is why

25 It is now available online (Dicționar explicativ al limbii române. $<$ http://dexonline.ro>. [online]. [cit. 28-10-2020].), together with other dictionaries. To note that this site is NOT the site of the Romanian Academy (as it should), but the initiative of some enthusiastic IT specialists. The first edition is COTEANU, I., SECHE, L., SECHE, M. (ed.) Dicţionarul explicativ al limbii române (DEX). Bucureşti: Editura Academiei, 1975. 
a new etymological dictionary of Romanian is necessary, one in which such old, persistent errors are removed, and which employs a more reasonable approach to the substratum heritage of Romanian, and of other cultural and linguistic areas.

\section{Final remarks}

The analysis presented here has tried to answer basic questions regarding the role of ideology (that is, for the most part, of politics and political ideology) in the etymological and historical study of Romanian and other southeast European languages over approximately the past century and a half. It is noteworthy that though there are a plethora of etymological dictionaries of Romanian, none are particularly reliable and/or complete. The extant etymological dictionaries of Romanian may be badly conceived (Cihac, and part of the 19 th c. $^{26}$ ) or wonderfully planned, but in either case are incomplete (Candrea-Densusianu, beginning of the 20 th $\mathrm{c}^{27}$ ) or simply incoherent, even if, as in the case of Vinereanu ${ }^{28}$, their goal is impressively ambitious. Amongst other examples of limited approaches that ignore the very important contribution of the substratum in the structure of Romanian one might note the work of Alexandru (Alejandro) Ciorănescu (Cioranescu), initially published in Spain, where the author emigrated after WW II ${ }^{29}$, and of Raevskij-Gabinskij on the 'Moldovan language'30. One observes two conflicting approaches to the issue of substratum inheritance in Romanian. On the one hand, there has been a persistent reluctance to consider the issue to be significant at all and, on the other, the 'thracomaniacal' or 'dacomaniacal' overemphasis given to the issue in other work.

From a purely academic perspective, ideological considerations should not intrude into the study of historical and comparative linguistics. Academic analyses as such are either good or bad, and should be independent of religious or political considerations. Unfortunately, the various and convoluted social and political contexts observed in eastern and southeast Europe, during the communist period and at other times as well, have had a strong influence on academic analyses and will probably continue to do so. The disposition toward viewing history through a political and ideological lens is so

26 CIHAC, A.: Dictionnaire étymologique daco-romane, I-II. 1870-1879. Frankfurt.

27 CANDREA, I.-A., DENSUSIANU, O.: Dicţionarul etimologic al limbii române. Elementele latine (a-putea). București: Socec, 1914 .

28 VINEREANU, M.: Dicționarul etimologic al limbii române. București: Alcor, 2008.

29 CIORĂNESCU, A.: Dicționarul etimologic al limbii române. București: Saeculum I.O., 2002; the work was initially published in Spain as fascicles under the title Diccionario etimológico rumano. La Laguna, $1960 \mathrm{ff}$.

30 RAEVSKIJ, N. D., GABINSKIJ, M. (eds.): Scurt dicţionar etimologic al limbii moldoveneşti. Chişinău: Redacţia Enciclopediei Sovietice Moldoveneşti, 1978. 
deeply rooted in the area that it is impossible to escape it easily. But we must hope this situation will change at some better time in the future.

I should also add that the scope of this analysis has been limited to a consideration of the basic issues involved in the relation between the historical and politico-ideological context, on the one hand, and humanistic studies, on the other, as manifested over time. I have tried to highlight the basic issues, with their ups and downs across time. These attempts, old and new, towards a coherent analysis of Romanian and other neighbouring languages (mainly those included in the so-called Balkansprachbund) and its complex heritage have been erroneous or incomplete, hesitant and often convoluted, or all of these at once.

After 1965, in the period of 'communism with human face', there was an obvious increase in the volume of etymological analysis that has continued through the 1970's and 1980's, with more or less relevant deviations towards either ignoring substratum heritage or exaggerating it. The so-called 'national communism' which gradually developed in Romania and other communist countries in the 1970s had its direct or indirect influence, but it may be labelled as having a limited or contextual effect on scientific research; the two fields, science and politics, developed more or less in parallel, though there was frequent interference from the communist régime whenever an approach seemed to deviate from the 'party line'. But this was usual all over the communist world in those times.

Since 1990, the younger generations of historians and linguists have focussed on areas of investigation whose ideological and political content is clear: the interwar period, the rise and development of the extreme right in the 1930s and its relations with Nazi and fascist movements, WWII, postwar period and the communist régime. Such topics are more attractive for most people, who are less inclined to engage with complex topics like the Pre-Indo-European heritage, prehistoric Europe, the Indo-European invasions, the emergence of ancient civilisations, the Roman conquest, the fall of the Roman Empire, the period of migrations etc. This explains, to a large extent, the development of what has come to be called dacomania or thracomania ${ }^{31}$, generally presented as an entirely 'natural' phenomenon that does not require complex levels of analyses. As there is no clear and constant concern with presenting research in an accessible form-what in French is called haute vulgarisation-the domain of pseudo-specialists is open to anybody inclined to consider himself or herself a specialist. The tragic result is that such self-defined specialists have often come to control scientific life

31 Dacomania and thracomania are specific ideological and political developments which were born precisely in uneducated circles, and supported by various political circles for which the real, genuine research is not relevant as compared to the political and ideological processing of history and historical heritage. See, for example, Dacomania sau cum mai falsificãm istoria. <https://www.historia. ro/sectiune/general/articol/dacomania-sau-cum-mai-falsificam-istoria>. [online]. [cit. 29-10-2020]. 
with their banal, often plagiarised works, and with an aggressive attitude towards, and derogatory language regarding, their predecessors and their contemporary colleagues. Fortunately, time selects. Unfortunately, this may happen too slowly or too late.

\section{Acknowledgements}

The author expresses his gratitude to Shelly Harrison for his suggestions and corrections.

\section{References}

BICHIR, G.: Cultura carpică. Bucureşti: Editura Academiei, 1973.

BICHIR, G.: Dacii liberi din Muntenia şi relaţiile lor cu romanii. Thraco-dacica 2, 1981, pp. 73-92.

BICHIR, G.: Geto-dacii din Muntenia în epoca romană. Bucureşti: Editura Academiei, 1984 .

BICHIR, G.: Ramura nordică a dacilor-costobocii. Thraco-dacica 4, 1-2, 1983, pp. 59-68.

BLAŽEVIĆ, Z.: SRPSKI ilirizam prije ILIRIZMA: NACIONALNO-IDENTIFIKACIFSKI modeli u historiografskim djelima grofa ĐORĐA BRANKOVIĆA (1645-1711). Književna istorija 44, 146, 2012, pp. 23-39. ISSN 0350-6428.

BOERESCU, P.: Elementele de substrat (autohtone) ale limbii române. Compendiu. București: Editura Academiei Române, 2018. ISBN 978-973-27-2969-4.

BONFANTE, G.: Studii române. București: Saeculum I. O., 2001. ISBN 973-9399-83-5.

BRÂNCUŞ, G.: Cercetări asupra fondului traco-dac al limbii române. București: Institutul Român de Tracologie, Bibliotheca Thracologica VIII, 1995.

BRÂNCUŞ, G.: Concordanțe lingvistice româno-albaneze. București: Institutul Român de Tracologie, Bibliotheca Thracologica XXX, 1999.

BRÂNCUŞ, G.: Vocabularul autohton al limbii române. Bucureşti: Editura Știinţifică şi Enciclopedică, 1983.

CANDREA, I.-A., DENSUSIANU, O.: Dicţionarul etimologic al limbii române. Elementele latine (a-putea). Bucureşti: Socec, 1914.

CIHAC, A.: Dictionnaire étymologique daco-romane, I-II, 1870-1879. Frankfurt.

CIORĂNESCU, A.: Dicționarul etimologic al limbii române. București: Saeculum I.O., 2002. ISBN 973-9399-86-X.

COTEANU, I., SECHE, L., SECHE, M. (eds) Dicţionarul explicativ al limbii române (DEX). Bucureşti: Editura Academiei, 1975. 
Dacomania sau cum mai falsificãm istoria. <https://www.historia.ro/sectiune/general/ articol/dacomania-sau-cum-mai-falsificam-istoria>. [onine]. [cit. 29-10-2020].

Dicționar explicativ al limbii române. <http://dexonline.ro>. [online]. [cit. 28-10-2020]. Enda - Carpica. <http://www.enciclopedia-dacica.ro/?operatie=subiect\&locatie= periodice \&fisier $=$ carpica $>$. [online]. [cit. 28-10-2020].

HASDEU, B. P.: Scrieri istorice, I-II. Bucureşti: Albatros, 1973.

HASDEU, B. P.: Studii de lingvistică şi filologie. Ed. by Gr. Brâncuş, 2 vols. Bucureşti: Minerva, 1988.

Muzeul Hasdeu. <http://www.muzeulhasdeu.ro>. [online]. [cit. 28-10-2020].

IONESCU, A. I.: Pavel fosef Šafařík și slavistica românească. București: Oscar Print, 2017. ISBN 978-973-668-459-3.

IVĂNESCU, G.: Istoria limbii române. Iaşi: Junimea, 1980.

PALIGA, S.: Este boieria o instituţie împrumutată? Revista Arhivelor 67, vol. 52, 3, 1990, pp. 250-26o. ISSN 1453-1755.

PALIGA, S.: Slovansko *szto - izzivalen problem? (in Slovene with an English abstract: Slavic *szto-a challenging problem?). Slavistična Revija (Ljubljana) 36, 4, 1988, pp. 349-358. ISSN 0350-6894.

PALIGA, S.: The Albanian Ethnogenesis, an 'Enigma'? A brief answer to Genc Lafe. In honorem Dagmar Maria Anoca. Ed. by Antoaneta Olteanu. București: Editura Universității București, 2016, pp. 303-316. ISBN 978-606-16-0755-6.

PALIGA, S.: Bogdan Petriceicu Hasdeu: první lingvista a slavista v Rumunsku (Bogdan Petriceicu Hasdeu: the first linguist and slavist in Romania). Literature and Social Change: a Voyage Through the History of Slavic Studies. Proceedings of the International Symposium Literature and Slavic Studies held by the Commission for the History of Slavic Studies at Comenius University in Bratislava on the 12th and 13th of April 2016. Edited by L'ubor Matejko. Bratislava: Univerzita Komenského, 2017, pp. 131-140. ISBN 978-80-971479-3-8.

PHILIPPIDE, A.: Originea românilor (the origin of the Romanians), vols. I-II. Iaşi, $1923-1928$.

POGHIRC, C.: B. P. Hasdeu, lingvist şi filolog. Bucureşti: Ed. Științifică, 1968.

POGHIRC, C.: Influenţa autohtonă, in Rosetti et alii (ed.), Istoria limbii române, 2 vols., 1965-1969, vol. 2, pp. 313-364.

PUŞCARIU, S.: Limba română. Bucureşti: Minerva, 1976. 1st ed.: Bucureşti 1940.

RĂDULESCU, M. M.: Daco-Romanian-Baltic Common Lexical Elements. Ponto-Baltica 1 (Editrice Nagard), 1981, pp. 15-113.

RĂDULESCU, M. M.: Illyrian, Thracian, Daco-Mysian, the substratum of Romanian. The Journal of Indo-European Studies 12, 1-2, 1984, pp. 77-131. ISSN 0092-2323.

RĂDULESCU, M. M.: The Indo-European Position of Illyrian, Daco-Mysian and Thracian. The Journal of Indo-European Studies 15, 1987, pp. 239-271. ISSN 0092-2323. 
RAEVSKIJ, N. D., GABINSKIJ, M. (eds.): Scurt dicţionar etimologic al limbii moldoveneşti. Chişinău: Redacţia Enciclopediei Sovietice Moldoveneşti, 1978.

ROSETTI, A.: Istoria limbii române, fully revised, final edition. Bucureşti: Editura Științifică şi Enciclopedică, 1986 (with several previous editions).

RUSSU, I. I.: Etnogeneza românilor. Bucureşti: Editura Științifică și Enciclopedică, 1981. RUSSU, I. I.: Obîrșia tracică a românilor și albanezilor. (Clarificări comparativ-istorice și etnologice). Der thrakische Ursprung der Rumänen und Albanesen. (Komparativ-historische und ethnologische Klärungen). Romanian-German bilingual edition, translated by Konrad Gündisch. Cluj-Napoca: Dacia, 1995. ISBN 973-350-4823.

SIMENSCHY, T., IVĂNESCU, G.: Gramatica comparată a limbilor indo-europene. Bucureşti: Editura Didactică şi Pedagogică, 1981.

SKOK, P.: Slavenstvo i romanstvo na jadranskim otocima. Toponomastička ispitivanja. Zagreb: Jugoslavenska akademija znanosti i umjetnosti, 1950.

VINEREANU, M.: Dicționarul etimologic al limbii române. București: Alcor, 2008. ISBN 978-973-816-0347.

VRACIU, A.: Limba daco-geților. Timişoara: Facla, 1980.

\section{About the author}

\section{Sorin Paliga}

University of Bucharest, Faculty of Foreign Languages and Literatures, Department of Russian and Slavic Philology, Bucharest, Romania

sorin.paliga@lls.unibuc.ro

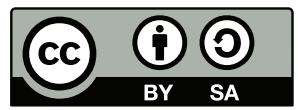

This work can be used in accordance with the Creative Commons BY-SA 4.0 International license terms and conditions (<https://creativecommons.org/licenses/by-sa/4.0/legalcode>). This does not apply to works or elements (such as images or photographs) that are used in the work under a contractual license or exception or limitation to relevant rights. 